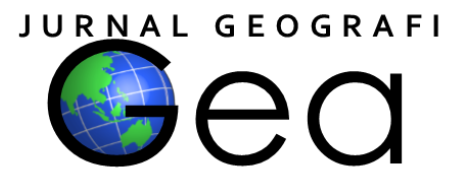

\title{
ANALYSIS OF REGIONAL LEADING SECTOR THROUGH LOCATION QUOTIENT APPROACH, SHIFT SHARE ANALYSIS, AND KLASSEN TYPOLOGY (CASE STUDY: SANGGAU REGENCY, WEST KALIMANTAN PROVINCE)
}

\author{
Diah Trismi Harjanti ${ }^{1}$, Muhammad Iqbal Apriliyana ${ }^{2}$, Audi Cindra Arini ${ }^{3}$ \\ ${ }^{1}$ Tanjungpura University, Pontianak City \\ ${ }^{2}$ Indonesian Association of Urban and Regional Planners \\ ${ }^{3}$ Tanjungpura University, Pontianak City \\ 1'diah.trismiharjanti@fkip.untan.ac.id, ${ }^{2}$ geoplanolog@gmail.com \\ 3audi.cindraarini@student.untan.ac.id
}

\begin{abstract}
Development of the economy is a must for a region, even though the region is classified as prosperous and prosperous. However, the level of affluence and affluence must be increased, at least be guarded, based on this basis economic development is still needed. To optimize the direction of economic development, it's necessary to know the potential sectors in Sanggau Regency, so it can generate significant economic growth. This research had the purpose to describe the pattern of changes in economic growth and determine the potential sectors in Sanggau Regency, so the results can be taken into consideration in policy formulation and future development planning in Sanggau Regency. The method that was used in this research is descriptive with a quantitative approach. The analysis data technique uses 3 approaches: the Location Quotient (LQ) Analysis Method, Shift Share (SSA) and Klassen Typology. Sectors in Sanggau Regency which are classified as regional superior sectors include Agriculture, Forestry and Fisheries, Mining and Quarrying, and Processing Industries. Therefore, it's hoped that the regional development strategy will prioritize the leading sectors in the area.
\end{abstract}

Keywords: LQ, SSA, Klassen, Potential Sectors

\section{INTRODUCTION}

Fair distribution of development in Indonesia is the real challenge that must be created, considering the condition of Indonesia as an archipelagic country. Diversity of potential and geographical obstacles like the difference of resource potential land in every region affect accessibility. The establishment of a region of being a growth center, can result in fringe areas whose value is more marginal from center. It can contribute to the development gap as a result of the differences in economic growth at local, regional, national, and global.

Economic development is part of a process that makes community per capita income in a region increase over a long period of time (Hasan and Aziz, 2018). According to Untoro in Yuniarti (2020) shows economic growth is a condition where economic activity develops, which can cause goods and services to be produced and distributed to the affluent community to increase in the long term. Economic growth is to be good if regions with low productivity will increase per capita income so that it can speed up processes.

Efforts and policies in order to improve the level of public affluence and regional economic relations and realize the transfer of primary sector economic activities into secondary and tertiary sectors are part of the objectives of economic growth. The form of government effort in improving the economy of a region is to continue to carry out 
sustainable development in various sectors so that it can spur high growth (Soleh and Maryoni, 2017).

According to Adisasmita in Lantemona, et al. (2014) that regional development is a function of the availability of potential natural resources, labor, and human resources, investment, development infrastructure and facilities, transportation and communication, industrial composition, technology, economic conditions and trade between regions. Regional economic development consists of establishing new institutions, developing alternative industries, increasing the capacity of the existing workforce to produce better products and services, identifying new markets, and transferring knowledge, and developing companies (Sari, 2016).

Changes in the economic sector can affect improvement of other related economic sectors. Region can be said to be advanced if there is support for high community knowledge, the availability of adequate natural resources, and managed by human resources who have the potential to improve regional development (Syahputra, Hamzah, and Syahnur, 2015). For measuring the growth performance of the economic sector, it's necessary to have indicators used. Indonesia also has documentation of data that presents economic growth as Gross Regional Domestic Product (GRDP). GRDP is the basis for measuring added value due to the emergence of various economic activities in an area (Badan Pusat Statistik, 2008).

Necessity of local governments to decentralize as a result of the enactment of Law Number 32 of 2004 concerning Regional Government and Law Number 33 of 2004 concerning Financial Balance between the Central Government and Regional Government so as to encourage regional economic growth.

The role of the economic sector is one of the cornerstones of regional development will determine the success of the development sectors initiated and subsequently realized by the regional government. Therefore, an important factor that must be emphasized by local governments in the context of accelerating regional development is through efforts to build an understanding of a healthy bureaucratic system and planned dynamic and pro-people economic development programs (Wenda and Akib, 2015). This is intended to realize the affluence of the community in accordance with the objectives of implementing regional autonomy, namely to improve public services and advance the regional economy. Through regional autonomy, local governments are required to innovate and be creative in improving the economy of their respective regions.

Sanggau is one of the regencies in West Kalimantan Province which has autonomous authority in the administration of government and regional development. In order for the utilization of this authority to work properly, there needs to be planning, processing and utilizing the superior potential of the existing sector in Sanggau Regency optimally so that all communities in. The roles of various economic sectors have an impact on determining the economic structure in a region. The economic structure formed from the added value generated by each sector can describe the magnitude of the regional dependence on the production capacity of each economic sector.

Based on the value of the GRDP of Sanggau Regency on the basis of current prices per year 2020, it reaches Rp. 19.95 trillion. This GRDP value has increased by Rp. 0.76 trillion compared to 2019 which reached Rp. 19.19 trillion (Badan Pusat Statistik, 2021). The increase in the value of GRDP that occurs is influenced by a series of economic developments that has been carried out in Sanggau Regency in various fields of business. Economic development becomes a necessity for a region, even though the region is a prosperous and prosperous region. This level of affluence and affluence must be increased, at least maintained, on the basis of this economic development is still needed.

To optimize the direction of economic development itself, it's necessary to know the potential sectors in Sanggau Regency, so that it can generate significant economic growth. The purpose of this research is to describe the pattern of changes in economic growth and determine the potential sectors in Sanggau Regency, so that it can be taken into 
consideration in policy formulation and future development planning in Sanggau Regency.

\section{RESEARCH METHOD}

The method used in this research is descriptive with a quantitative approach. The source of data in this study is secondary data in the form of time series data on gross regional domestic income in Sanggau Regency published by BPS Sanggau Regency.

\section{Location Quotient (LQ)}

LQ is a method that uses the comparison of the share of employment/ production/added value in a particular sector in a region with the share of employment/ production/added value in the same sector throughout the country (Yuuhaa \& Cahyono, 2013). The LQ method aims to determine the leading sector in an area. This economic base theory was put forward by Harry W. Richardson in Lolowang (2014) which states that the main determinants of regional economic growth are directly related to the demand for goods and services from outside the region. From the point of view of the economic base theory, each region is an integrated socio-economic system.

Basically, LQ analysis results in a relative comparison between the capacity of a sector in the surveyed area and the capacity of the same sector in a wider area. According to Bendavid-Val in Sapriadi, et al (2015), the formula is follows:

$$
L Q=\frac{X_{i}^{r} / X^{r}}{X_{i}^{n} / X^{n}}
$$

Note:

$X_{i}^{r} \quad=$ Output Sector/Subsector in the region/district

$X_{i}^{n} \quad=$ Output Sector/Subsector in the region/province

$\mathrm{Xr}=$ Total Output Sector/Sub-sector in the region/district

$\mathrm{Xn}=$ Total Output Sector/Sub-sector in the region/Province

If $L Q>1$ This means that the industrial sector/sub-sector is the leading sector in the district and has the potential to be developed as a driver of the regional economy.

If $L Q<1$ This means that the industrial sector/sub-sector is not superior in the district and less has the potential to be developed as a driver of the regional economy.

\section{Shift Share (SSA)}

Shift-share analysis held to find out that there were some changes and a shift or sector of industry in the regional economy or local economy. Shift-share analysis describes the performance of sectors in the micro-region which is then compared with the economy of the wider region. If regions have made progress according to its position in the economy to greater so it can find any shift or shifts from the results of the economic development in an area. In addition, by comparing the growth rate of sectors in a region with a wider area and its sectors, an analysis of the deviations arising from this comparison is then carried out. If the deviation result is positive, hence called competitive seed of sectors from the is in the area (Hidayat, 2013)

Shift-share analysis used to analyze the economic changes in sector/industry regional variables in a region. Variable where for an analysis is the number of workers or the availability of job opportunities, added value, Gross Regional Domestic Product (GRDP), population, and other variables within a certain period of time.

According to Soepomo in Hidayat (2013), the shift components, namely Mij and Cij function to separate the elements of regional growth that have external and internal characteristics: $\mathrm{Mij}$ is the result of the influence of external elements that work in the Regency, while Cij is the result of the influence of factors that work within the district concerned. The Shift Share calculation method used is as follows:

Note:

$$
\text { Dij }=\text { Nij }+ \text { Mij }+ \text { Cij }
$$

Shift Share (Dij): shows the shift of the sectors in a region. 
Regional Growth Effect (Nij): shows the influence of the growth of each district on the economy of West Kalimantan Province.

Proportional Shift (Mij): shows the relative change in the performance of a sector in the district against the same sector in the province. Differential Shift (Cij): shows the competitiveness of a sector in the district against the same sector in the province.

\section{Klassen Typology}

Klassen type analysis is used to explain the pattern and structure of regional sector growth. Each economic sector of each region can be divided into prime sectors, developing sectors, potential sectors, and underdeveloped sectors. This analysis is based on grouping by looking at the growth and income of the sector which is represented using a matrix or Cartesian diagram.

\section{RESULTS AND DISCUSSION}

\section{Results}

1. Location Quotient (LQ)

Identification of leading sectors in Sanggau Regency using LQ analysis. Location Quotient (LQ) analysis can be done as a prefix to determine policy making related to the development of the existing economic sector. The results of the LQ calculation are as follows:

Table 1. LQ Calculation Results

\begin{tabular}{lc}
\hline \multicolumn{1}{c}{ Economic Sector } & $\begin{array}{c}\text { Location Quotient (LQ) } \\
\text { Value }\end{array}$ \\
\hline Agriculture Forestry \& Fisheries & 1.48 \\
Mining \& Quarry & 1.57 \\
Processing industry & 1.04 \\
Electricity \& Gas Supply & 2.94 \\
Water Supply Waste Management \& Recycling & 2.49 \\
Construction & 0.60 \\
Wholesale \& Retail; Car \& Motorcycle Repair & 0.78 \\
Transportation \& Warehousing & 0.36 \\
Provision of Accommodation, Food \& Drink & 0.77 \\
Information \& Communication & 0.96 \\
Financial Services \& Insurance & 0.55 \\
Real Estate & 0.94 \\
Company Services & 0.60 \\
Government Administration of Defense \& Social Security & 0.97 \\
Mandatory & 0.69 \\
Education Services & 0.83 \\
Health Services \& Social Activities & 0.60 \\
Other services & \\
\hline
\end{tabular}

Source: Data analysis (2021)

Sectors that get an LQ value of more than 1 are leading sectors, while sectors that get an LQ value of less than 1 are not leading sectors and have less potential for further development. From Table 1 above, it's known that there are 5 leading sectors in Sanggau Regency, namely Agriculture, Forestry and Fisheries, Mining and Quarrying, Processing Industry, Electricity and Gas Procurement, and Water Supply, waste management, waste and recycling. The lowest LQ value is the transportation and warehousing sector with an LQ value of only 0.36 .

\section{Shift Share (SSA)}

Shift Share (SSA) analysis describes the performance of sectors in a micro-region compared to the economy of the wider region. So that in conducting this Shift Share (SSA) analysis, data at the micro level in this case is Sanggau Regency as well as economic data for the 
Province of West Kalimantan. The results of the shift share calculation are as follows:

\section{a. Calculation of Regional Growth Effect (Nij)}

Table 2. Regional Growth Effect Calculation Results

\begin{tabular}{lccc}
\hline \multicolumn{1}{c}{ Economic Sector } & $\begin{array}{c}\text { GRDP of } \\
\text { Sanggau } \\
\text { Regency } \\
2019\end{array}$ & $\begin{array}{c}\text { Total GRDP Growth of } \\
\text { West Kalimantan } \\
\text { Province } 2019\end{array}$ & $\begin{array}{c}\text { Regional } \\
\text { Growth Share } \\
\text { (NGS) }\end{array}$ \\
\hline Agriculture Forestry \& Fisheries & A & B & AXB \\
Mining \& Quarry & $4,371.46$ & 0.05 & 218,660 \\
Processing industry & 932.42 & 0.05 & 46,640 \\
Electricity \& Gas Supply & $2,232.51$ & 0.05 & 111,670 \\
Water Supply Waste Management \& & 37.86 & 0.05 & 1,894 \\
Recycling & 44.44 & 0.05 & 2.223 \\
Construction & & & 38,933 \\
Wholesale \& Retail; Car \& Motorcycle & $1,475.35$ & 0.05 & 73.797 \\
Repair & & 0.05 & 9.533 \\
Transportation \& Warehousing & 190.58 & 0.05 & 11.151 \\
Provision of Accommodation, Food \& & 222.94 & 0.05 & 30.901 \\
Drink & & & 13,380 \\
Information \& Communication & 617.78 & 0.05 & 16,863 \\
Financial Services \& Insurance & 267.50 & 0.05 & 1,771 \\
Real Estate & 337.13 & 0.05 & 32.145 \\
Company Services & 35.40 & 0.05 & 17,408 \\
Government Administration of Defense \& & 642.65 & 0.05 & 7,811 \\
Social Security Mandatory & & & 4.119 \\
Education Services & 348.02 & 0.05 & 0.05 \\
Health Services \& Social Activities & 156.16 & 0.05 & \\
Other Services & 82.35 & & \\
\hline \multicolumn{1}{c}{ AMOUNT } & $12,772.90$ & & 500 \\
\hline
\end{tabular}

The Regional Growth Share Value is used to see the effect of each sector in the regency of the provincial economy. The Regional Growth Share value is obtained from the multiplication of the Regency's GRDP value with the Province's total GRDP growth. Then the value of the Regional Growth Share will
Source: Data analysis (2021) be obtained. Based on Table 2, it's known that the sector that has the most influence on economic growth in the Province of West Kalimantan is the Agriculture Forestry and Fisheries sector.

\section{b. Calculation of Proportional Shift (Mij)}

Table 3. Proportional Shift Calculation Results

\begin{tabular}{lcccc}
\hline Economic Sector & $\begin{array}{c}\text { GRDP of } \\
\text { Sanggau } \\
\text { Regency }\end{array}$ & $\begin{array}{c}\text { GRDP Sector } \\
\text { Growth of West } \\
\text { Kalimantan } \\
\text { Province }\end{array}$ & $\begin{array}{c}\text { Total Sectoral } \\
\text { Growth of GRDP of } \\
\text { West Kalimantan } \\
\text { Province }\end{array}$ & $\begin{array}{c}\text { Industrial } \\
\text { Mix Share } \\
\text { (IMS) }\end{array}$ \\
\hline $\begin{array}{l}\text { Agriculture Forestry \& } \\
\text { Fisheries }\end{array}$ & $4,371.46$ & 0.06 & $\mathrm{C}$ & A x (BC) \\
\hline
\end{tabular}




\begin{tabular}{lcccc} 
Mining \& Quarry & 932.42 & 0.06 & 0.05 & 10,141 \\
Processing industry & $2,232.51$ & 0.07 & 0.05 & 55.520 \\
Electricity \& Gas Supply & 37.86 & 0.06 & 0.05 & 0.263 \\
Water Supply Waste & 44.44 & 0.05 & 0.05 & -0.111 \\
$\begin{array}{l}\text { Management \& Recycling } \\
\text { Construction }\end{array}$ & 778.35 & 0.01 & 0.05 & -33.255 \\
$\begin{array}{l}\text { Wholesale \& Retail; Car \& } \\
\text { Motorcycle Repair }\end{array}$ & $1,475.35$ & 0.06 & 0.05 & 7,975 \\
$\begin{array}{l}\text { Transportation \& } \\
\text { Warehousing }\end{array}$ & 190.58 & 0.04 & 0.05 & $-2,539$ \\
$\begin{array}{l}\text { Provision of Accommodation, } \\
\text { Food \& Drink }\end{array}$ & 222.94 & 0.07 & 0.05 & 3.376 \\
$\begin{array}{l}\text { Information \& } \\
\text { Communication }\end{array}$ & 617.78 & 0.06 & 0.05 & 8.384 \\
$\begin{array}{l}\text { Financial Services \& } \\
\text { Insurance }\end{array}$ & 267.50 & -0.03 & 0.05 & $-20,695$ \\
Real Estate & 337.13 & 0.03 & 0.05 & -6.781 \\
Company Services & 35.40 & 0.05 & 0.05 & -0.024 \\
Government Administration of & 642.65 & 0.06 & 0.05 & 5.519 \\
$\begin{array}{l}\text { Defense \& Social Security } \\
\text { Mandatory }\end{array}$ & & & & \\
$\begin{array}{l}\text { Education Services } \\
\text { Health Services \& Social }\end{array}$ & 348.02 & 0.04 & 0.05 & -3.752 \\
$\begin{array}{l}\text { Activities } \\
\text { Other services }\end{array}$ & 156.16 & 0.07 & 0.05 & 3.269 \\
\hline & 82.35 & 0.08 & 0.05 & 2,686 \\
\hline & $12,772.90$ & & 504,867 \\
\hline
\end{tabular}

Source: Data analysis (2021)

The Proportional Shift Value is used to view changes in the performance of each sector in the Regency with the same sector at the provincial level. The Proportional Shift value is obtained from the multiplication of the subtraction value between the sector growth in the GRDP of the regency and the total growth of the

Table 4. Differential Shift Calculation Results

\begin{tabular}{lcccc}
\hline \multicolumn{1}{c}{ Economic Sector } & $\begin{array}{c}\text { GRDP of } \\
\text { Sanggau } \\
\text { Regency }\end{array}$ & $\begin{array}{c}\text { Sanggau Regency } \\
\text { GRDP Sectoral } \\
\text { Growth }\end{array}$ & $\begin{array}{c}\text { GRDP Sector } \\
\text { Growth of West } \\
\text { Kalimantan } \\
\text { Province }\end{array}$ & $\begin{array}{c}\text { Local } \\
\text { Share (LS) }\end{array}$ \\
\hline Agriculture Forestry \& Fisheries & $4,371.46$ & 0.05 & 0.06 & A x (BC) \\
Mining \& Quarry & 932.42 & 0.07 & 0.06 & -22.060 \\
Processing industry & $2,232.51$ & 0.00 & 0.07 & $-162,760$ \\
Electricity \& Gas Supply & 37.86 & 0.06 & 0.06 & -0.057 \\
Water Supply Waste Management & 44.44 & 0.04 & 0.05 & -0.142 \\
\& Recycling & & & & \\
Construction & 778.35 & 0.07 & 0.01 & 52.062 \\
Wholesale \& Retail; Car \& & $1,475.35$ & 0.05 & 0.06 & -1.012 \\
Motorcycle Repair & & & &
\end{tabular}


Transportation \& Warehousing

Provision of Accommodation,

Food \& Drink

Information \& Communication

Financial Services \& Insurance

Real Estate

Company Services

Government Administration of

Defense \& Social Security

Mandatory

Education Services

Health Services \& Social

Activities

Other services
190.58

222.94

617.78

267.50

337.13

35.40

642.65

348.02

156.16

82.35
0.08

0.07

0.07

0.00

0.03

0.04

0.00

0.03

0.02

0.08
0.04

0.07

0.06

$-0.03$

0.03

0.05

0.06

0.04
$-4.406$

$-7,340$

$-0.495$

7,486

0.893

5,604

6,735

$-0.252$

$-0.397$

$-37.115$

$-156.007$
AMOUNT

The Differential Shift value is used to see the competitiveness of each sector in the Regency with the same sector at the provincial level. The value of Differential Shift is obtained from the multiplication between the value of the reduction in the value of sector growth in the GRDP of the Regency and the growth of the GRDP

Source: Data analysis (2021) sector at the provincial level. Then the value of Differential Shift will be obtained. Based on Table 4 it's known that the sector with the highest competitiveness is the construction sector.

\section{d. SSA Calculation Recapitulation}

Table 5. SSA Calculation Recapitulation Results

\begin{tabular}{ccc}
\hline Industrial Sector SSA Components & Score & Criteria \\
\hline $\mathrm{Nij}$ & 638,900 & + \\
$\mathrm{Mij}$ & 66,867 & + \\
$\mathrm{Cij}$ & -156.007 & - \\
\hline
\end{tabular}

Source: Data analysis (2021)

The results of calculations using the Shift Share method showing the potential sectors in each sub-district can be seen in the table below:

Table 6. Explanation of the Assessment of the Three Components

Rating result

Information

1. Fast growth

2. The sector in the sub-district grows faster than the sector in the district has a locational advantage

3. The sector in the sub-district has high competitiveness or the sector has the potential to be developed

1. Fast growth

2. The sector in the sub-district grows faster than the sector in the district has a locational advantage

3. The sub-district sector does not have competitiveness or the sector has no potential to be developed

1. Fast growth

2. The sub-district sector grows slower than the district sector or the sector does not have a locational advantage

3. The sector in the sub-district has high competitiveness or the sector has the potential to be developed

1. Fast growth 
2. The sub-district sector grows slower than the district sector or the sector does not have a locational advantage

3. The sub-district sector does not have competitiveness or the sector has no potential to be developed

Source: Data analysis (2021)

\section{Klassen Typology}

To find out the description of the development of the pattern and structure of economic growth in Sanggau Regency,
Klassen Typology analysis was used. The results of the calculation of the Klassen typology are presented in the image below:

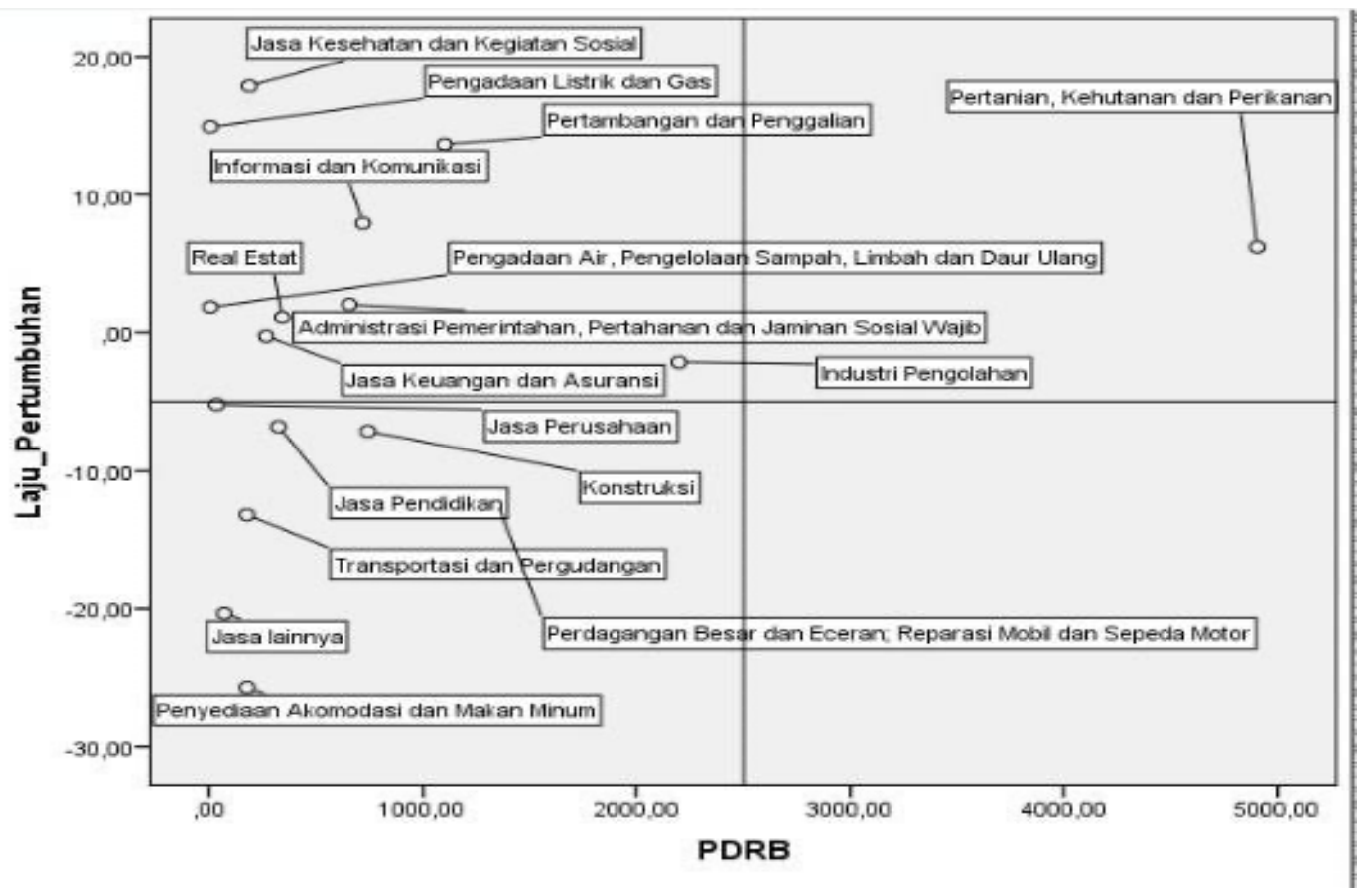

Figure 1. Klassen Typology Calculation Results

From Figure 1. above, it can be seen that the calculation results using the Klassen typology analysis show that of the 17 sectors in Sanggau Regency, there is only one sector belongs to quadrant I, namely the agricultural, forestry, and fishery sectors. While the other 16 sectors are scattered between quadrant II and quadrant IV.

\section{Discussion}

\section{Location Quotient (LQ)}

From the results of calculations that have been carried out using the LQ formula in Table 1, it's known that there are 5 sectors which are the base sectors in Sanggau Regency. This is because the LQ value obtained for the five sectors is greater than 1. Similarly with this research, based on researched by Mulyono and Munibah (2016) stated that commodities that have a comparative advantage indicates that the commodity is produced through dominance of natural resource support, where the region others are unable to produce it

The five leading sectors in Sanggau Regency itself consist of, Agriculture, Forestry and Fisheries, Mining and Quarrying, Processing Industry, Electricity and Gas Procurement, and Water Supply, waste management, waste and recycling.

The Agriculture, Forestry, and Fisheries Sector obtained an LQ score of 1.48. The Mining and Quarrying Sector obtained an LQ score of 1.57. The Manufacturing Industry Sector obtained an LQ score of 1.04. The Electricity, Gas, and Water Supply Sector obtained an LQ score of 2.94. Meanwhile, the Waste Management, Waste and Recycling sector obtained an LQ score of 2.49. Meanwhile, the remaining 12 other sectors obtained 
LQ values below 1, which means these sectors have not become leading sectors and have less potential to be developed as drivers of regional economic growth.

The Sanggau Regency government needs to focus on developing five leading sectors so that it's expected to continue to increase regional economic growth. The focus in developing leading sectors in the regions is due to the fact that each sector is included in the leading sector, then the sector has the potential which, if developed, will have more influence on income. As for the five leading sectors in Sanggau Regency, the Electricity, Gas, and Water Procurement sector is the most superior sector among other sectors.

\section{Shift Share (SSA)}

\section{a. Regional Growth Effect (Nij)}

Regional Growth Effect (Nij) is used to see the influence of each sector in the Regency on the provincial economy. So, by doing this Nij analysis, it will be known how the contribution of the existing sectors at the regional level to economic growth at the regional level province. From the calculation results in order to obtain the Regional Growth Effect value obtained for each of these sectors is: The Agriculture Forestry \& Fisheries sector got a score of 218,660, the Mining \& Quarrying sector got a score of 46,640 , the Manufacturing Industry sector got a score of 111,670, the Construction sector got a score of 38,933 and Wholesale \& Retail Trade; Car \& Motorcycle Repair got a score of 73,797. while the sector with the smallest influence on the economy of West Kalimantan Province is the Corporate Services sector with a value of 1,771 .

\section{b. Proportional Shift (Mij)}

Proportional Shift (Mij) is used to see changes in the performance of each sector in the Regency with the same sector at the provincial level. Thus, from the results of the analysis using the Mij it can be seen how the level of performance development of each sector at the regional level affects economic growth at the provincial level. From the results of calculations carried out to determine the Proportional Shift value in Sanggau Regency which is contained in Table 3, it's known that 3 sectors in Sanggau Regency that have the best performance changes consist of Agriculture Forestry \& Fisheries, Mining \& Quarrying, and Processing Industry.

The Proportional Shift value obtained by each sector is. The Agriculture, Forestry \& Fisheries sector with a score of 36,890 , the Mining \& Quarrying sector with a proportional shift value of 10,141 , and the Manufacturing Industry sector with a score of 55,520 which is the highest score among other sectors. Meanwhile, the sector with the lowest Proportional Shift value is the construction sector.

\section{c. Differential Shift (Cij)}

Differential Shift (Cij) is used to see the competitiveness of each sector in the Regency with other regions in the same province. By knowing the competitiveness of each sector through the Cij analysis, it is able to facilitate decision making that requires the development of sectors that have high competitiveness in one province. From the results of the calculation to get the Differential Shift value in Sanggau Regency which is contained in Table 4, it's known that the most competitive sector in Sanggau Regency against the same sector at the West Kalimantan Province level is the Construction sector. The value of Differential Shift in the construction sector is 52,062 .

When viewed as a whole, the value of Differential Shift in Sanggau Regency was obtained at a value of 156.007. The total acquisition value obtained negative results, because many sectors in Sanggau Regency 
obtained negative results as well. This means that many sectors in Sanggau Regency are not able to compete with sectors at the provincial level.

\section{d. SSA Calculation Recapitulation}

From the results of the SSA calculations that have been carried out, it's known that there are 2 components, namely $\mathrm{Nij}$ and $\mathrm{Mij}$ which have positive final results and 1 component, namely $\mathrm{Cij}$, which has negative final results. So, from the results of the assessment, it's known that the economic growth that occurs in Sanggau Regency is relatively fast, the sectors in the sub-districts are growing faster than the sectors in the district, which means these sectors have locational advantages but unfortunately the sectors in the subdistricts do not have competitiveness or sectors it's not potential to be developed.

The results obtained are the same as the research conducted by Kasikoen (2018) which states that shift-share analysis can be used to describe conditions of the economy in a region, comparison growth to more areas broad, knowing the sectors that progressing, identifying sectors that are superior, somewhat superior, backward, a bit backwards.

\section{Klassen Typology}

The description of the pattern and structure of regional sectoral growth using Klassen typology analysis is classified into prime, developing, potential and underdeveloped sectors. If the sector point shows its presence in quadrant I, it's classified as a prime sector, which means that the sector has potential and a higher growth rate and per capita income. The developing sector is indicated by the presence of dots on the diagram in quadrant II, meaning that the sector in this quadrant is progressing but at the same time experiencing pressure. Progress in quadrant II means that the sector has a higher per capita income, but is also under pressure in the form of lower economic growth.

In the Potential sector or those in quadrant III, it means that the sector is experiencing fairly rapid development. The condition of the sector which is in quadrant III has a high growth rate, but the level of per capita income is lower. The last is the sector that is classified as underdeveloped, in this case the point is in quadrant IV. The sector which is in quadrant IV has a low growth rate and per capita income.

When viewed from the results of the classification of typology calculations that have been carried out and presented in Figure 1, it can be seen that the agriculture, forestry, and fisheries sectors are sectors that are included in the prime sector in Sanggau Regency.

Meanwhile, the sectors classified as developing in Sanggau Regency are in quadrant II consisting of 9 sectors, namely the manufacturing industry, financial services and insurance, real estate, water supply, waste, waste and recycling management, government administration, defense, and insurance. mandatory social services, information and communication, mining and excavation, electricity and gas procurement, as well as health services and social activities.

The remaining 7 sectors in Sanggau Regency are included in the lagging sector group. The 7 sectors consist of the corporate services sector, construction, education services, transportation and warehousing, wholesale trading, retail, car and motorcycle repair, provision of food and drink accommodation and other services.

That means that each sector in Sanggau Regency has a different level of competitiveness and control factors. This is in accordance with research conducted by Alhempi, et al (2014). The results of shift-share show potential sectors for each district/city in Riau Province. Economic growth in districts/cities is driven by the effect of provincial growth, the effect of industry mix, and the effect of competitive advantage. Each district/city has different 
competitive sectors with different driving factors.

\section{CONCLUSIONS}

Based on the LQ calculation, it can be concluded that the leading sectors in Sanggau Regency are Agriculture, Forestry and Fisheries, Mining and Quarrying, and Processing Industries. Meanwhile, based on the results of Shift share, it can be concluded that the existing sectors are experiencing rapid growth but unfortunately are not competitive. Meanwhile, based on the calculation of the Klassen typology, it can be concluded that the agricultural, forestry and fisheries sectors are sectors that have the potential to be developed.

\section{RECOMMENDATIONS}

The suggestion that can be given is for the local government to formulate a development strategy the development of which in accordance with the existing potential, namely by prioritizing leading activities in the form of: Agriculture, Forestry and Fisheries, Mining and Quarrying, and Processing Industries.

\section{REFERENCES}

Alhempi, R. R., Zainal, H., \& Kusumastuti, S. Y. (2014). Keterkaitan Sektor-Sektor Ekonomi Potensial Kabupaten/Kota Sebagai Dasar Kebijakan Pembangunan Ekonomi Di Provinsi Riau. MIMBAR, 30(1), 62-71.

Badan Pusat Statistik. (2008). Pedoman Praktis Perhitungan PDR Badan Pusat Statistik. Pedoman Praktis Perhitungan PDRB Kabupaten/Kota Pengertian Dasar. Jakarta: Cv.Nario Sari

Badan Pusat Statistik. (2021). Produk Domestik Regional Bruto Kabupaten Sanggau Menurut Lapangan Usaha 2016-2020. Sanggau: Badan Pusat Statistik

Hidayat, R. (2013). Analisis Komoditas Unggulan Subsektor Perkebunan di Kabupaten Bengkayang Provinsi Kalimantan Barat. Jurnal Sosial Ekonomi of Agriculture, 2(1), 56-66.

Hasan, M., \& Azis, M. (2018). Pembangunan Ekonomi \& Pemberdayaan Masyarakat:
Strategi Pembangunan Manusia dalam Perspektif Ekonomi Lokal. Makassar: $\mathrm{Cv}$. Nur Lina \& Pustaka Taman Ilmu.

Kesuma, N.L.A., \& Utama, I.M.S. (2015). Analisis Sektor Unggulan dan Pergeseran Pangsa Sektor-sektor Ekonomi Kabupaten Klungkung Jurnal Ekonomi KuantitatifTerapan, 8(1), 169179.

https://ojs.unud.ac.id/index.php/jekt/arti cle/view/16503/10800

Kasikoen, K. M. (2018). Analisis Shift Share Untuk Perencanaan Wilayah (Studi Kasus-Kabupaten Bogor) Pendahuluan Metode analisis ekonomi yang digunakan untuk mengetahui pengembangan pada suatu wilayah, ditunjukkan berdasarkan kondisi posisi sektor wilayah yang lebih luas. Forum Ilmiah, 15(3), 442-228. https://www.esaunggul.ac.id/wp-content /uploads/2019/02/9.-Analisis-Shift-Shar e-Untuk-Perencanaan-Wilayah-StudiKasus---Kabupaten-Bogor.pdf

Lantemona, A., Kalangi, J.B., \& Naukoko, A. (2014). Analisis Penentuan Kota Manado Sektor Unggulan Perekonomian. Jurnal Berkala Ilmiah Efisiensi, 14(3), 15-29. https://ejournal.unsrat.ac.id/index.php/jb ie/article/download/5459/4966

Lolowang, R., Luntungan, A., \& Tumilaar, R. (2014). Analisis Potensi Pertumbuhan Ekonomi Kabupaten Minahasa (Pendekatan Model Basis Ekonomi Dan Daya Saing Ekonomi). Jurnal Berkala Ilmiah Efisiensi, 14(3), 94-104. https://ejournal.unsrat.ac.id/index.php/jb ie/article/ download/ 5517/5044

Mulyono, J., \& Munibah, K. (2016). Pendekatan Location Quotient Dan Shift Share Analysis Dalam Penentuan Komoditas Unggulan Tanaman Pangan Di Kabupaten Bantul. Informatika Pertanian, 25(2), 221. https://doi.org/10.21082/ip.v25n2.2016. p221-230

Sapriadi, \& Hasbiullah. (2015). Analisis Penentuan Sektor Unggulan Perekonomian Kabupaten Bulukumba. Jurnal Iqtisaduna, 1(1), 71-86. http://journal.uin-alauddin.ac.id/index.p 
$\mathrm{hp} /$ Iqtisaduna/article/download/1155/11 21

Sari, D.M. (2016). Analisis PermasalahanPermasalahan Usaha Kecil Dan Menengah Sektor Jasa Di Kota Bengkulu. Jurnal Ekonomi Dan Perencanaan Pembangunan (JEPP), 6(3), 60-71. http://repository.unib.ac.id/ 11568/1/ANALISIS

PERMASALAHANPERMASALAHAN USAHA KECIL DAN MENENGAH SEKTOR JASA.pdf

Soleh, A., \& Maryoni, H.S. (2017). Analisis Sektor Ekonomi Unggulan Dan Hubungannya Dengan Kesempatan Kerja Dan Investasi Di Kabupaten Batanghari. Jurnal Ekonomi-Qu, 7(1), $15-30$. https://doi.org/10.35448/jequ.v7i1.4183

Syahputra, H., Hamzah, A,. \& Syahnur, S. (2015). Analisis Sektor Unggulan Dan Perubahan Struktur Perekonomian Kabupaten Aceh Barat. Jurnal Ilmu Ekonomi, 3(3), 56-68. http://jurnal.unsyiah.ac.id/MIE/article/d ownload/4752/4101

Takalumang, V.Y., Rumate, V.A., \& Lapian, A. L. C. P. (2018). Analisis Sektor Ekonomi Unggulan Dalam Mendorong Pertumbuhan Ekonomi Kabupaten/Kepulauan Sangihe. Jurnal Berkala Ilmiah Efisiensi, 18(01), 1-12. https://ejournal.unsrat.ac.id/index.php/jb ie /article/ download/19154/18712

Undang-Undang Republik Indonesia Nomor 32 Tahun 2004 Pemerintahan Daerah. 15 Oktober 2004. Lembaran Negara Republik Indonesia Tahun 2004 Nomor 125.Jakarta.

Undang-Undang Republik Indonesia Nomor 33 Tahun 2004 Perimbangan Keuangan antara Pemerintah Pusat dan Pemerintahan Daerah. 15 Oktober 2004. Lembaran Negara Republik Indonesia Tahun 2004 Nomor 126.Jakarta.

Wenda, W.L., \& Akib, H. (2015). Pembangunan Ekonomi Dalam Era Otonomi Daerah Di Kabupaten Pegunungan Bintang, Indonesia. Jurnal Ilmiah Ilmu Administrasi Publik, 5(1), 43-51. https://doi.org/10.26858/jiap.v5i1.1079

Yuniarti, P., Wianti, W., \& Nugraheni, N.E. (2020). Analisis Faktor-faktor yang Mempengaruhi Tingkat Pertumbuhan Ekonomi di Indonesia. SERAMBI: Jurnal Ekonomi Manajemen Dan Bisnis Islam, 2(3), 169-176. https://doi.org/10.36407/serambi.v2i3.2 07

Yuuhaa, M.I.W., \& Cahyono, H. (2013). Analisis Penentuan Sektor Basis dan Sektor Potensial Di Kabupaten Lamongan. Jurnal Pendidikan Ekonomi (JUPE), 1(13), 1-15. https://core.ac.uk/ download/pdf/230751692.pdf 